\title{
The Peace Puzzle:
}

\section{A Study of Afghanistan Peace Process}

Mohammad Mahdi Zaki

November 2018 


\section{Introduction}

The peace process in Afghanistan has been ongoing for several years without having made any significant progress. Since 2001, the Afghan government has undertaken a number of initiatives aimed at making peace with the Taliban, mostly designed to convince them to give up their military campaign (Kaura, 2018, p. 5). President Hamid Karzai, by initiating the High Peace Council (HPC) in 2010, offered the Taliban a peace deal which included the removal of their names from terrorist blacklists, if they renounced ties with the al-Qaeda, abandoned violence, and pursued their political goals in accordance with the Afghanistan Constitution. The Taliban rejected Karzai's overtues and responded with renewed campaign against the government. The National Unity Government (NUG) under Ashraf Ghani made a peace offer to the Taliban that included recognition of the group as a political party, the removal of sanctions, release of prisoners, and a review of the constitution. On 7 June 2018, the Afghan government announced a unilateral week-long nationwide ceasefire with the Taliban. Two days later, the Taliban responded with a three-day ceasefire (Thomas, 2018). Further to peace initiatives by Kabul, the US diplomats have also met with the Taliban to discuss reconciliation and peace. These have increased expectations for a peace agreement and possibly an end to a four-decades lasting conflict in Afghanistan. However, both the government and the Taliban remain unclear in their demands at the peace negotiations. This essay seeks to understand the instances of the parties involved in the Afghan conflict and what they seek from the peace process. In particular, the essay attempts to answer the following questions:

- What are the sources of conflict in Afghanistan?

- What is peace according to the Taliban and the Afghan government?

- What are the challenges to reaching a peace agreement in Afghanistan?

\section{Methodology}

It is a qualitative research and the data is collected through in depth-interviews with the Afghan government spokesperson, the High Peace Council, Former UN Special Representative to Afghanistan, a former official within the Taliban Emirate and Afghanistan analysts.

\section{Taliban and Al-Qaeda in Afghanistan}

The Afghan jihad against the communist regime of Kabul and the Soviet troops in Afghanistan during the 1980s brought about 20000 jihadist from all over the world strengthened with financial and military support by the USA, Saudi Arabia, China and Pakistan (Chaliand \& Arnaud, 2007, p. 293). Abdullah Azzam was among the first Islamists coming to Pakistan and 
he established "Maktab al-Khimat ul-Mujahideen ul-Arab", to better organize the jihadists in 1984. Osama bin Laden, who had close ties with Saudi leadership families joined him and after Azzam's death in a car bomb in 1989, became the leader of the network and renamed it as "AlQaeda" (Mojdeh, 2002, p. 36).

After the Afghan jihad ended and the Mujahidin took over Kabul in April 1992, they failed to establish a government as the Mujahidin remained fragmented along ethnolinguistic, tribal, sectarian and personality lines. People were deeply disappointed with this situation and the battle between these groups took lives of ordinary civilians every day. People were waiting for a savior and it didn't matter to them whom and from where it would appear (Mojdeh, 2002, p. 12). It was in this chaotic situation that a group of previously-Mujahid Pashtuns, who had fought against the USSR troops and the PDPA regime, seized control over Spin Boldak on 10 October 1994, and a month later over Kandahar province. They were called Taliban, the Islamic students who promised to restore peace and security and not to establish a government. According to Vahid Mojdeh", "the objectives stated by the Taliban movement at first, were ideal goals for the Afghan public: Disarmament of individuals and unauthorized groups, providing public safety, secure roads and lifting all checkpoints. Before entering Kabul in September of 1996, the Taliban alleged that they had no intention of ruling Afghanistan." (Mojdeh, 2002, p. 21). However, analysts have underlined the ethnic basis of the Taliban movement. Since the establishment of Afghanistan as an independent state in 1747 by Ahmad Khan Abdali, the country's rulers had always been from among the Pashtuns (Schetter, 2003, p. 1) except the six months reign of Habibullah Kalakani in 1929. When the regime of President Najeebullah collapsed in April 1992, the Mujahidin took the power in which non-Pashtun leaders were the majority. After two months of Sebghatullah Mujaddadi's rule, Burhanuddin Rabbani, who was a Tajik, became the president. It was, according to Anwar ul Haq Ahadi, a decline of Pashtuns' power in Afghanistan and the Taliban generated optimism among the Pashtuns about a reversal of their decline (Ahadi, 1995, p. 624). When the Taliban took over Kabul in 1996, they announced Islamic Emirate and Mullah Mohammad Umar as the Amir al-Mominin (Commander of the Faithful). To expand their rule over the country, the Taliban committed serious human rights violations and killed hundreds of innocent civilians, specifically the Hazaras who according to the Taliban were not Muslims (Rashid, 2000, p. 69). Taliban captured the northern city of Mazar-i Sharif in August 1998 and killed at least 2000 civilians most of whom were Hazaras and similarly, when they took over Bamian in 2000, they killed more than 170 Hazara men in four days (Human Rights Watch, 2001). They applied their own austere

\footnotetext{
1. Vahid Mojdeh is a former official within the Taliban Emirate.
} 
version of Sharia in the country. Men were required to grow beards and women had to wear an all-covering burka and were not allowed to work or to go out alone. The schools for girls were closed and the female nurses and doctors were forbidden from doing their job (Rashid, 2000, p. 85).

During the Taliban rule over Kabul, Afghanistan became safe haven to thousands of desperate young Muslims as they viewed Afghanistan as a stronghold against the West and from there hoped to find a safe haven for taking revenge against oppression in Palestine, Chechnya and Kashmir. Taliban, in need of money and troops to defeat their enemies, welcomed them with open arms (Mojdeh, 2002, p. 65). Following Osama's call for jihad against Saudi Arabia and the USA, al-Qaeda members exploded US embassies in Kenya and Tanzania in August 1998. The US forces bombarded the al-Qaeda training centers in Afghanistan and US and Saudi Arabia demanded Taliban deliver Osama bin Laden to them, but the Taliban refused (Zaeef, 2010, p. 131). In the aftermath of the $9 / 11$ attacks, which killed nearly 3,000 people from 93 nations, the US government swiftly identified Osama Bin Laden as the prime suspect and insisted that the Taliban immediately hand over the terrorists and close the training camps or face an attack from the US. When they refused, "Operation Enduring Freedom" was launched on 7 October 2001 and ended the Taliban regime on 9 December 2001 (Frontline, 2006).

After the US-led operation in Afghanistan ended the Taliban Emirate in two months, NATO and the Afghan government were optimistic about ending the insurgency in the country and by late 2005, considered the insurgency mostly defeated. This optimistic assessment proved misplaced when violence increased significantly in mid-2006. According to Mojdeh, the military campaign during the 2001 had forced the Taliban to hide, but they did not surrender. After the US got busy in Iraq and the Afghan government failed to deliver services to the people in the villages, the Taliban realized the vacuum and they felt strong enough to restart their battle (Mojdeh, 2018). NATO-led operations during 2006-2008 cleared key districts but did not prevent subsequent re-infiltration. By 2008, the US and NATO officials admitted to this failure and the US then-Joint Chief of Staff Chairman Admiral Mike Mullen stated, "I am not sure we are winning" in Afghanistan. Considering the security deterioration, the US and its allies in NATO increased their forces in Afghanistan. Obama increased the US forces to 100000 with a 30000 NATO forces, but NATO officials in Lisbon Summit in 2010 decided gradual transition of security responsibilities to Afghan leadership that would be completed by the end of 2014 (Katzman, 2016, p. 22). To continue cooperation after 2014, Kabul and Washington signed the Security and Defense Cooperation Agreement (SDCA) also called the Bilateral Security Accord 
(BSA) on 30 September 2014 which allows around 10000 US troops to remain in Afghanistan along with about 2000 NATO troops (The Embassy of Afghanistan, Washington DC, 2014).

Today, after 17 years of NATO forces presence and military efforts, Afghanistan security is still threatened by insurgent groups, all of which are allied with each other. According to a report by the Integrity Watch Afghanistan, the security situation in Afghanistan is deteriorating rapidly and Taliban now control more territory than at any time since 2001 . The same report underlines that $79 \%$ of the respondents consider insecurity as the major problem (Integrity Watch Afghanistan, 2016, p. 11). The Taliban, Haqqani Network, al-Qaeda and the Islamic State (IS) are the main insurgent groups which are actively in fight with the Afghan government and the international forces in the country.

The Taliban movement still lead the insurgency against the Afghan government. Taliban leader, Mullah Omer, died in 2013, but his death was revealed in July 2015. In a disputed selection process, Akhtar Mohammad Mansour became the leader with two deputies - Sirajuddin Haqqani and Haibatullah Akhunzadeh, but the opponents of Mansour's selection centered around Umar's son, Mohammad Yaqub, who asserted that Pakistan had planned the leadership of Mansour. Akhtar Mansour was killed by a US strike in Baluchistan, Pakistan on 23 May 2016 when he was returning from Iran. Several days after the death of Mansour, the Taliban confirmed his death and announced the selection of Akhundzadeh as the new Taliban leader. According to Deputy Spokesperson to the Afghan President Shahhussain Murtazai, the Taliban fight has provided opportunity for more than 20 terrorist groups to be active in Afghanistan including the IS (Murtazawi, 2018).

The Haqqani Network operates under the Taliban and was founded by Jalaluddin Haqqani who fought against the USSR and later served as Minister of Tribal Affairs in Taliban regime. The Haqqani Network had about 3,000 fighters and supporters at its peak during 2004-2010, but it is believed to have far fewer currently; however, the network is still capable of carrying out operations, particularly in Kabul city (Katzman, 2016; 21).

Al-Qaeda has minimal presence in Afghanistan and operates as facilitators for the Taliban and the Islamic Movement of Uzbekistan (IMU). After the 9/11 attacks, al-Qaeda was largely driven out of Afghanistan by US-supported Afghan forces. In December 2001, American forces failed to prevent Osama bin Laden's escape after his location was revealed to be in Tora Bora mountains, but he was later killed on 1 May 2011 in Abbottabad, Pakistan. His successor, Ayman al-Zawahiri, is presumed to be on the Pakistani side of the border (Katzman, 2016; 20). 
The IS has been active in Afghanistan since mid-2014 and its presence grew further as additional Taliban factions defected to the group and captured some small areas primarily in eastern Afghanistan. Mojdeh believes that the IS is being supported by the Afghan government and the US forces as it fights the Taliban (Mojdeh, 2018). Its members also include former fighters of the Taliban and according to Kristian Berg Harpviken², IMU members have changed their loyalty and are now operating under the label of IS in northern Afghanistan (Harpviken, 2018). IS has commenced several deadly attacks on civilian targets specially on the Hazaras and Shi'as.

According to the Afghan government, Taliban is an Afghan insurgent network; while al-Qaeda and the IS are founded by foreigner and therefore, the peace process includes only the groups originated from Afghanistan (Taliban) not the al-Qaeda and the IS (Hamid, 2018; Murtazawi, 2018).

\section{Peace with the Taliban}

The peace process in Afghanistan has been ongoing for several years without having made any significant progress. Since 2001, the Afghan government has undertaken a number of initiatives aimed at making peace with the Taliban, mostly designed to convince them to give up their military campaign (Kaura, 2018, p. 5). President Hamid Karzai offered the Taliban a peace deal by conducting, first, a National Consultative Peace Loya Jirga ${ }^{3}$ in 2010. Following the Loya Jirga, the government established the High Peace Council (HPC) to follow the peace talks with the Taliban (Özerdem, 2015, 449). Hamid Karzai's reintegration plan aimed to offer the Taliban the removal of their names from terrorist blacklists, if they renounced ties with the al-Qaeda, abandoned violence, and pursued their political goals in accordance with the Afghanistan Constitution. However, the Taliban rejected Karzai's overtues and responded with renewed campaign against the government. The Chief of the High Peace Council, Burhanuddin Rabbani was assasinated by the Taliban in 2011 (Kaura, 2018, p. 6). The start of Taliban office in Doha, Qatar in June 2013, which had the Taliban flag over its building was criticized by the Afghan government as the latter claimed it was the implicit recognition of the Taliban's shadow government, and so the office was closed 24 hours after it had opened. Talks did not restart

\footnotetext{
2. Kristian Berg Harpviken, who has written extensively about Afghanistan since 1898 and has worked in the country, was interviewed in February 2018 by the author.

3. Jirga is made up of tribal and local leaders that decides on different issues including social and economic issues at the national level (Sheets, 2012, p. 22). The 2004 Constitution which was ratified in a jirga in 2004, has constitutionalized the jirga under the 'Chapter 6: Loya Jirga'. Article 110 of the Constitution states, "The Loya Jirga is the highest manifestation of the will of the people of Afghanistan." The Constitutional Loya Jirga is different from the traditional Loya Jirga. The decisions made by the Constitutional Loya Jirga are legally binding; while a traditional Loya Jirga is more of a consultative one.
} 
extensiveuntil the inauguration of Ashraf Gahni as the new president in September 2014 (Farrell \& Semple, 2017, p. 3).

The National Unity Government (NUG) under Ashraf Ghani accepted the Doha Office of the Taliban as the main channel for peace talks and there have been several talks between the Afghan government officials with Taliban representatives (Hamid, 2018). At the $2^{\text {nd }}$ Kabul Process conference in February 2018, President Ghani made a peace offer to the Taliban that included recognition of the group as a political party, the removal of sanctions, release of prisoners, and a review of the constitution. He repeated his offer in a conference in March held at Tashkent, Uzbekistan. President Ghani's bold peace offer to the Taliban has aroused hopes for peace in the country. Further, On 7 June 2018, President Ghani announced a unilateral weeklong nationwide ceasefire with the Taliban coinciding with the end of Ramadan. Two days later, the Taliban responded with a three-day ceasefire. During the ceasefire, the Taliban members came to the cities and took pictures with the Afghan forces. On 16 June, the Afghan government unilaterally extended the ceasefire for another ten days, but the Taliban rejected the offer (Thomas, 2018). The Taliban believe that the Afghan government is not the final decisionmaker on issues regarding peace in the country and, therefore, they have always insisted on talking directly to the US (Kaura, 2018, p. 10). Recently, the Taliban representatives attended a conference in Moscow on 9 November in which representatives of ten countries including Iran, Pakistan, India and Central Asian republics attended. Afghanistan government did not send any representative, but the HPC delegation attended the conference (Ferris-Rotman, 2018).

\section{Sources of the Conflict}

The Afghan conflict is multi-dimensional, involving Afghan, regional and global actors. Due to its complexity, no single actor holds the key to resolving the crisis and therefore, the interests and concerns of these actors shall be taken into consideration.

\subsection{Domestic Sources of the Conflict}

The Taliban rise was at the chaotic situation created because of the civil war between different Mujahidin and they promised to restore peace and security. Similarly, the failure of the post2001 Afghan government to provide good governance, maintain security in all parts of the country and an endemic corruption have given them the reason to reemerge (Hamid, 2018; Mojdeh, 2018; Sarabi, 2018). Admitting to this failure, Former UN Special Representative to 
Afghanistan Kai Eide ${ }^{4}$ believes that it has left the security situation worsening; corruption in the government has become endemic; and the country is politically and ethnically divided (Eide, 2017). Arne Strand ${ }^{5}$ also considers corruption as one of the biggest problems in the country which shall be stopped (Strand, 2017). Afghanistan is one of the most corrupt country in the last years with widespread corruption in all the branches of government. According to Integrity Watch Afghanistan 2016 Report, "both in the percentage of the population that admits to having paid bribes, and the overall amount of money lost to bribes, the rise is significant. More than $26 \%$ of Afghans say they have had to pay a bribe in the past 12 months, with an overall economic loss of over $\$ 2.8$ billion - significantly higher than the estimated $\$ 2.17$ billion the Afghan government expects to generate in domestic revenues this year." (Integrity Watch Afghanistan, 2016, pp. 24-25).

Currently, Taliban control more territory than at any point since the removal of their regime in 2001. A BBC report in January 2018 showed that the Taliban were in full control of 14 district (4\% of the country) and had active and physical presence in a further $263(66 \%)$ of the country which leaves only 122 districts (30\%) under the control of the government; however, it does not mean they were free of violence (Sharifi \& Adamou, 2018). The Taliban have now established several commissions including the health, agriculture and tax, education, military, electricity, and judicial commission (Mojdeh, 2018). Taliban bureaucrats collect taxes and electric bills and their judges hear civil and criminal cases (Jackson, 2018, p. 20).

\subsection{External Sources of the Conflict}

The external factor is so much influential in the Afghan conflict that most of the Afghans including the government officials believe the Taliban will not last without foreign aid. According to Habiba Sarabi ${ }^{6}$ and Abdul Rehman Hamid ${ }^{7}$, Afghanistan is the arena of proxy war of other countries. Pakistan-India and Iran-Saudi Arabia rivalry is played in Afghanistan. Taliban are being supported by Pakistan, Iran and Russia as they seek to influence in Afghanistan (Sarabi, 2018; Hamid, 2018).

\footnotetext{
${ }^{4}$. Kai Eide who was the UN Special Representative to Afghanistan from 2008 to 2010 was interviewed in August 2017 by the author.

5. Arne Strand who has been involved in humanitarian activities and research about Afghanistan for more than 30 years was interviewed by the author in February 2017.

6. Habiba Sarabi is the Deputy Chair to High Peace Council and Senior Advisor on Women to the Chief Executive of Afghanistan.

7. Abdul Rehman Hamid is Head of the Research Department at the High Peace Council.
} 
Pakistan has always sought to assure that a pro-Pakistan Pashtun dominated government is instablled in kabul so that it can solve its border disputes, supports Islamabad in the conflict with New Delhi and also it could help Pakistan to reach the potentially resource-rich Central Asian republics. After the Mujahidin started the civil war in 1992, Pakistan saw its plan in vain, but the emergence of the Taliban in 1994 provided them the chance and Pakistan supported the Taliban who were described as 'our boys' by Pakistan's then-Interior Minister (Rashid, 2002, p. 53). Islamabad officially recognized the Taliban as the legitimate government of Afghanistan in May 1997 and urged the rest of the world to do the same (Saikal, 2012, p. 227). After the 9/11 attacks, Islamabad was forced to break with the Taliban and join the coalition led by the US (Setas, 2013, p. 8). Pakistan provided information and logistical support to the US to help overthrow the Taliban; however, following the military defeat of the Taliban regime, thousands of its fighters and al-Qaeda members crossed the Pakistani border and found refuge in the tribal areas of the country. The existence of this safe zone for the Taliban poses a serious threat to the stabilization of Afghanistan. Although Islamabad has initiated several operations against the insurgent groups in its territory, they have not helped with ending terrorist network. Major failure on the part of Pakistan is due to the policy of making distinction between "good militants" and "bad militants" which has been a major factor contributing to the deterioration of the situation (Spanta, 2017, p. 693).

Kabul believes that Pakistan has an inevitable role in bringing Taliban to the negotiation table as Taliban have been fighting for years and they could not continue to this without being supported by a country. The Taliban's reliance on Pakistan for military logistics, medical care and sanctuary for the insurgents remains as critical as ever and Islamabad still holds the key to getting the Taliban to the table (Kaura, 2018, p. 16). According to Murtazawi, "the Taliban leadership council known as the "Quetta Shura" is in Pakistan; they recruit from among Pakistanis at the border areas; their wounded members get treatment in Pakistan hospitals; and their leaders live in Pakistan" (Murtazawi, 2018). Islamabad brokered the first round of direct talks between the Afghan government and Taliban in July 2015. However, so far Islamabad has maintained that it can only convince Taliban and cannot force them to negotiate with the Afghan government (Mojdeh, 2018).

Numerous NATO and US reports have accused Iran for providing support for the Taliban. According to Mojdeh, Tehran now holds better position regarding its influence over the Taliban as families of most of the Taliban leaders live in Iran (Mojdeh, 2018). Despite ideological difference Iran has established contacts with the Taliban to not completely lose the ground and also to avoid the possible security threat by the IS (Giustozzi, 2013; 72). Similarly, Russia has 
openly discussed of its relationship with the Taliban claiming that it is to avoid any threat to their interests in Afghanistan. Further to this, Moscow is keen to have closer relationship with the Taliban since the group fight the IS which poses serious threat to Central Asia and Russia security (Sarabi, 2018).

\section{Peace as the Absence of Violence}

Currently, the main question is how to end the war which, according to Galtung, is negative peace (Galtung J. , 1967, p. 12). All the stakeholders accept that war is not the solution. The HPC representative argues, "Everyone has realized that the problem cannot be solved by war. After the June ceasefire, we implemented a survey which showed that more than 70 percent of the respondents supported the ceasefire and around 90 percent demanded peace." According to him, the Taliban members doubt the rightfulness of their war as in June 2018, around 3000 religious clerics announced the war unjust and asked both the government and the Taliban to ceasefire and start negotiations. Therefore, the Taliban are seeking ways to end the war (Hamid, 2018). The US government officials have also stated that war is not the solution. Recently, the US Chairman of the Joint Chiefs of Staff Gen. Joseph Dunford during a discussion at a security forum in Halifax stated that the Taliban are not losing in Afghanistan and there would never be a military solution on its own to bring peace. He further added that the US is working with its NATO partners to leverage military, political and economic pressure to convince the Taliban it is in their interest to negotiate a political solution to the crisis (Crawford, 2018).

While the government of Afghanistan and its international allies insist that the peace talks shall be Afghan-led (Hamid, 2018); the Taliban have announced that the Afghan government is not the final decisionmaker on issues regarding peace in the country and, therefore, they have always insisted on talking directly to the US (Kaura, 2018, p. 10). Washington has backed Ghani's peace offering with repeated affirmation by their top diplomats and commanders of a political solution to the conflict. However, with Taliban dismissing the Afghan government as illegitimate and demanding negotiations with the US, the Trump Administration in July 2018 told its diplomats to seek direct talks with the Taliban. Since then, there have been several meetings between the US officials and Taliban representatives in Doha, Qatar, led by the Deputy Assistance Secretary of State Alice Wells and Special Representative for Afghanistan Reconciliation Zalmay Khalilzad (Al Jazeera, 2018).

\section{Conflicting and Ambiguous Instances in Peace Negotiations}


As the Afghan government states, the so far meetings have been for the start of the peace negotiations and the two sides have not reached any agreement. However, the stakeholders have different demands.

Taliban have not been clear about their demands and beyond references to the Sharia law, the Taliban's vision for the government after the withdrawal of foreign troops remains incomplete and ambiguous. Their messaging campaign fails to offer viable solutions or alternatives to the current situation. However, Mojdeh lists demands of the Taliban as the followings:

1. The Taliban demand compliance with Sharia which will be include all the laws and government policies.

2. The Taliban have realized that monopoly of the political power is not realistic and leads to war. Therefore, they accept other political groups.

3. They accept the Constitution but will demand it to be written and approved by the Afghans without any intervention by the foreigners.

4. The network will demand the reform of Afghan National Security Forces (ANSF);

5. The Taliban do not support the current democratic institutions such as the election and parliament. Instead, they refer to the Quran which says, “هَلْ يَسْتَوِى الََذِينَ يَعْلَمُونَ وَالَذِْينَ نَ يَعَعَمُونَ" (Are those who know equal to those who do not know?). They might demand other mechanisms such as Loya Jirga or Shura-Ahl-e-Hal o Aqd consisting of clerics.

6. The network will demand release of its prisoners and removal of names of its leaders from the terrorist black list.

7. The Taliban demand withdrawal of the US and NATO forces according to a timetable.

8. The Taliban do not seek to isolate Afghanistan as they did in the 1990s. They will seek to establish and maintain relationship with the outside world (Mojdeh, 2018).

However, insisting that the Taliban are a religious-political group, Mojdeh believes that the Ulema Council of the Taliban decides about these issues and even if they reach an agreement, the might ask Kabul to send a delegation consisting of the religious clerics so the Council can negotiate with them.

Although government officials have consistently stated that there is no pre-conditions for the start of negotiations and all the meetings have been preliminary, the HPC representative says that they are ready to accept the demand about the withdrawal of foreign troops, but it should be according to a timetable (Hamid, 2018). Similar to the Taliban, the government of Afghanistan has also not provided a clear peace plan with the Taliban. According to Mojdeh, Kabul does not have a clear peace plan and follows the US in this issue (Mojdeh, 2018). 
However, at the domestic level, the government has held meetings with different stakeholders including civil society representatives, women and religious clerics as a result, a 'Peace Advisory Board' is formed. The government has also formed a 12 persons negotiating team, led by the Chief of Staff for the President. In his remarks at Geneva Conference on Afghanistan, President Ghani announced the roadmap for peace negotiations. He added, "I am pleased to announce today that after several months of intensive consultations with citizens across the country, we have formulated a roadmap for peace negotiations. We have formed the required bodies and mechanisms to pursue a peace agreement. We are now moving ahead into the next chapter of the peace process." (President Ashraf Ghani's Remarks At Geneva Conference on Afghanistan, 2018). The President stated that they seek a peace agreement in which the Afghan Taliban would be included in a democratic and inclusive society, respecting the following tenets:

1. The Constitutional rights and obligations, of all citizens, especially women, are ensured;

2. The Constitution is accepted, or amendments proposed through the constitutional provision.

3. The Afghan National Defense and Security Forces and civil service function according to law.

4. No armed groups with ties to transnational terrorist networks or transnational criminal organizations, or with ties to state/non-state actors, seeking influence in Afghanistan will be allowed to join the political process (President Ashraf Ghani's Remarks At Geneva Conference on Afghanistan, 2018).

The last article illustrates a contradiction in government's peace plan. The Afghan government has always accused its neighbors of supporting the Taliban and even believe that the group cannot continue to its war in Afghanistan unless they are supported by others, specifically Pakistan. The Deputy Spokesperson to the President argues that the Taliban leadership council is in Pakistan; they recruit from among Pakistanis at the border areas; their wounded members get treatment in Pakistan hospitals; and their leaders live in Pakistan (Murtazawi, 2018). In the meantime, they seek peace with this group that is being supported by Pakistan and other countries.

At the international level, the government has sought to convince the neighboring countries that a peaceful Afghanistan is at their interests. Shall Afghanistan become a safe haven to the insurgent groups, these countries would also suffer from the insecurity (Hamid, 2018). 
The Taliban continue to deny the Afghan government is a legitimate party to the conflict or is worth talking to. Holding fast to this non-recognition stance, the Taliban have consistently denied reports of secret meetings between its representatives and those of the Afghan government outside Afghanistan. They have insisted on talking to the Americans as their real adversary (Osman, 2014). Although the US stance towards direct talks with the Taliban have increased the prospects for a negotiated end to the conflict, Mojdeh believes that no development has been made yet in the peace negotiations and the US representatives have only listened to the Taliban. He highlights the Taliban concerns about the US objectives and adds, "after the US withdrawal from Iran deal, the Taliban are skeptical about the negotiations. They have told if the US ignore the agreement, the possibility of negotiation will be dismissed forever." (Mojdeh, 2018).

Recalling the peace agreement with Gulbuddin Hekmatyar's Hezb-e Islami, the HPC representative argues, "it gives the Taliban a hope that they can also start a normal life like any other Afghan. It also questions the Taliban fight and shows that the Afghan government is honest in its call for peace with every insurgent group." (Hamid, 2018). Hezb-e Islami was one of the militant groups fighting against the Afghan government and international forces. After years of negotiation, Hekmatyar representatives and Afghan government signed an agreement on 22 September 2016. According to the agreement, Hezb-e Islami announced that it will no longer continue to its rebellious acts against the government and the Afghan citizens. The government had lobbied the US and the UN for the lifting of international sanctions on Hekmatyar, who was designated a global terrorist by the Washington for his suspected ties to al-Qaeda and the Taliban. He returned to Kabul after international sanctions were lifted. The peace agreement gives Hekmatyar and his followers immunity for past actions and grants them full political rights. However, Alexey Yusupov believes the deal is highly symbolical and it can help very little with the establishment of peace in the country as Hezb-e Islami's presence on the battlefield is fairly non-existent ("Afghanistan: Ghani, Hekmatyar Sign Peace Deal," 2016). The Afghan government is optimistic about reaching a peace agreement with the Taliban. Mojdeh also believe that negotiations can lead to peace if Taliban demands are taken into consideration (Mojdeh, 2018). This is while the HPC representative argues that an agreement with the Taliban may not end the conflict in the country, but it definitely decreases the war (Sarabi, 2018). 


\section{Challenges}

Despite a popular demand for peace, the fragmentation among the Taliban and also the lack of consensus among government leadership challenges the process.

\section{Divided Taliban}

The Taliban insurgency has divided internally into at least four main groups: Quetta Shura, Mashhad Shura, Shura of the North and the Rasool Shura. Due to this fragmentation, there is wide regional autonomy between various shuras of the Taliban. Although Quetta Shura is the main leadership council of the Taliban, competetion dictates that none of the three shuras recognize the authority of the Quetta Shura. In face, between 2015 and 2017, the Rasool Shura and the Quetaa shura were engaged in fight against each other (Kaura, 2018, p. 12). Mojdeh believes that after Mullah Omar's death, none of the Taliban leaders are considered as Amir alMominin as they have not been chosen by the jirga of Ulema. Their selection has been a strategic choice. Therefore, they do not have the authority of Mullah Omar and it has caused some fragmentation (Mojdeh, 2018). Despite this, the HPC representative states that they are ready to negotiate with all the insurgent groups no matter which faction they represent (Hamid, 2018). Furthermore, peace negotiations might be costly for the Taliban if their forces at the battlefield feel that they are ignored by their leadership in the peace talks. Mojdeh believes that if the Taliban members feel ignored, they might join other militant groups such as the IS. Therefore, the Taliban leadership has been careful about confirming their meetings with the US and Afghan government representatives (Mojdeh, 2018).

\section{Lack of Consensus among Government Actors}

The lack of consensus among government actors on what reconciliation with the insurgent means and the absence of a realistic strategy to achieve it greatly inhibits the peace process (Galvanek, 2014, p. 6). Various power centers within the Afghan government do not speak with one voice regarding the peace process. It is highlighted by the HPC representative as she states that the HPC has the same problem as members of the Council do not agree on an issue. According to her, the HPC do not have the capacity to carry on the peace negotiations. Furthermore, the HPC and the government efforts are not in coordinated. Therefore, she is skeptical about the result of peace talks and believes that it will not help with pace in the country (Sarabi, 2018). 


\section{Recommendations}

President Ghani, in his remarks at the Geneva Conference on Afghanistan, stated that lasting stability for Afghanistan is not the absence of bullets. For achieving positive peace, the followings shall be taken into consideration:

- A fair application of the rule of law and the protection of citizens' rights and freedoms are crucial for builiding the citizens' trust on government and reaching a lasting peace. The Afghan government's ability to preserve its cohesiveness, deliver key services, and provide security to the people can weaken the Taliban's tide.

- The liberty and status of women and question of minorities needs to be considered and safeguarded, since the Taliban hold extreme views on women and minorities.

- A broader and deeper reconciliation process must involve not just the Afghan government and the Taliban, but also political opposition actors, civil society actors and regional actors.

- The regional element of the war in Afghanistan, particularly the detrimental role of Pakistan, must be more openly and honestly addressed by the international community in order to both improve the relationship between Afghanistan's government and its international supporters and to build momentum for the peace negotiations.

- In Afghanistan, public support for the current peace negotiations is lacking, and this has become one of the factors affecting the relationship between the government on the one side, and civil society, the media and the Afghan citizens on the other side. The peace process must be made more transparent to inform the citizens as much as possible about the process to ensure its continued interest and support. Without a certain level of transparency and the dissemination of regular information, peace process would not meet the public's approval. 


\section{Bibliography}

\section{Interviews}

Eide, K. (2017, August 29). Regional Security: A Struggle to Overcome Afghanistan's Insulation through Multilateral Foreign Policy. (M. M. Zaki, Interviewer) Oslo.

Hamid, A. R. (2018, November 14). Research and Studies Director at the High Peace Council. (M. M. Zaki, Interviewer)

Mojdeh, V. (2018, November 13). Former Official within the Taliban Emirate. (M. M. Zaki, Interviewer)

Murtazawi, S. (2018, November 12). Deputy Spokesperson to the President. (M. M. Zaki, Interviewer)

Sarabi, H. (2018, October 7). Afghanistan Peace Process. (M. M. Zaki, Interviewer)

Strand, A. (2017, February 15). Afghanistan Security Problem and Regional Countries. (M. M. Zaki, Interviewer) Bergen.

\section{Books and Articles}

Ahadi, A. u. (1995, July). The Decline of the Pashtuns in Afghanistan. Asian Survey, 35(7), 621-634.

Al Jazeera. (2018, November 9). Afghanistan Peace Conference Kicks off in Moscow. Retrieved from https://www.aljazeera.com/news/2018/11/afghanistan-peaceconference-kicks-moscow-181109083021481.html

Ameri, N. S. (2011). Prospects for Peace and Stability in Afghanistan. SIPRI Afghanistan Regional Dialogue.

Chaliand, G., \& Arnaud, B. (Eds.). (2007). The History of Terrorism; From Antiquity to Al Qaeda. California: University of California.

Crawford, J. (2018, November 17). Top US Military Officer Says Taliban 'Are Not Losing'. Retrieved from CNN Politics: https:/edition.cnn.com/2018/11/17/politics/josephdunford-taliban-afghanistan/index.html

Donati, J., \& Nissenbaum, D. (2018, July 25). U.S. Envoy, Taliban Officials Meet to Discuss Afghan Peace Talks. Retrieved from The Wall Street Journal: https://www.wsj.com/articles/u-s-envoy-taliban-officials-meet-to-discuss-afghanpeace-talks- 1532547118

Farrell, T., \& Semple, M. (2017). Ready for Peace? The Afghan Taliban after a Decade of War. London: Royal United Services Institute. 
Ferris-Rotman, A. (2018, November 9). Moscow Shows It's Back in the 'Great Game' by Hosting Taliban-Afghan Peace Talks. Retrieved from The Washington Post: https:/www.washingtonpost.com/world/europe/in-a-first-moscow-prepares-to-hostafghan-talks-between-taliban-and-kabul-envoys/2018/11/08/1adffc42-e2a4-11e8b759-3d88a5ce9e19_story.html?utm_term $=.37 \mathrm{c} 6140 \mathrm{c} 171 \mathrm{c}$

Galtung, J. (1981). Social Cosmology and the Concept of Peace. Jounral of Peace Research, 18(2), 183-199.

Galtung, J. (1967). Theories of Peace: A Synthetic Approach to Peace Thinking. Oslo: International Peace Research Institute.

Galvanek, J. B. (2014). Supporting Negotiations for Peace in Afghanistan. Berlin: Berghof Foundation.

Human Rights Watch. (2001). Afghanistan: Massacres of Hazaras in Afghanistan. London: Human Rights Watch.

Integrity Watch Afghanistan. (2016). National Corruption Survey 2016. Integrity Watch Afghanistan, Kabul.

Jackson, A. (2018). Life under the Taliban Shadow Government. London: Overseas Development Institute.

Kaura, V. (2018). Understanding the Complexities of the Afghan Peace Process. New Delhi: Observer Research Foundation.

Mojdeh, V. (2002). Afghanistan Under Five Years of Taliban Sovereignty. (S. Khalili, \& S. Ganji, Trans.) Kabul.

Osman, B. (2014, January 24). The Future of Peace Talks: What Would Make a Breakthrough Possible? Retrieved from Afghanistan Analysts Network (AAN): https://www.afghanistan-analysts.org/the-future-of-peace-talks-what-would-make-abreakthrough-possible/

Panda, A. (2015, November 24). A Turning Point in Afghanistan-India Relations? Retrieved November 27, 2017, from The Diplomat: https://thediplomat.com/2015/11/whyafghanistan-and-india-are-about-to-transform-their-relationship/

President Ashraf Ghani's Remarks At Geneva Conference on Afghanistan. (2018, 1128$)$. Retrieved from Office of the President: https://president.gov.af/en/SP/789012781234 Rashid, A. (2000). Taliban: Militant Islam, Oil, and Fundamentalism in Central Asia. New Haven: Yale University Press.

Saikal, A. (2012). Modern Afghanistan: A History of Struggle and Survival. London \& New York: I. B. Tauris \& Co Ltd. 
Schetter, C. (2003). Ethnicity and the Political Reconstruction of Afghanistan. State Reconstruction and International Engagement in Afghanistan. Germany: Center for Development Studies (ZEF), University of Bonn.

Sharifi, S., \& Adamou, L. (2018, January 31). Taliban Threaten 70\% of Afghanistan.

Retrieved from BBC World Service: https://www.bbc.com/news/world-asia-42863116

Sheridan, M. (1998). How the Taliban Slaughtered Thousands of People. Retrieved from http://www.rawa.org/times.htm

The Constitution of Afghanistan. (2004). Ministry of Justice.

(n.d.). The Dawn of Afghan Peace or Another False Alarm?

The Embassy of Afghanistan, Washington DC. (2014, September). Bilateral Security

Agreement. Retrieved from The Embassy of Afghanistan, Washington DC:

https://www.afghanembassy.us/document/bsa/

Thomas, C. (2018, October 16). Momentum Toward Peace Talks in Afghanistan? Retrieved from CRS Insight: https://fas.org/sgp/crs/row/IN10935.pdf

Tiwary, S. (2016). Understanding Taliban and the Peace Process. New Delhi: Indian Council of World Affairs. Retrieved from https://www.researchgate.net/publication/303924565

Zaeef, A. S. (2010). My LIfe with the Taliban. (A. S. Linschoten, \& F. Kuehn, Eds.) New York: Columbia University Press. 